\title{
PSEUDOPREGNANCY IN MICE TREATED WITH OVINE PROLACTIN
}

\author{
B. T. GROFT AND A. BARTKE \\ Worcester Foundation for Experimental Biology, Shrewsbury, \\ Massachusetts 01545, U.S.A.
}

\section{(Received 2nd April 1975)}

In the laboratory mouse, prolactin is indispensable for luteal function (Choudary \& Greenwald, 1969), and pseudopregnancy can be induced by prolactin injections or by prolactin-producing pituitary grafts (Dresel, 1935; Browning \& White, 1963; Bartke, 1966; Dominic, 1966). During pregnancy, the minimal daily requirement for exogenous prolactin is greater during the first 2 days than during the following 6 days (Bartke, 1973), and the present study was undertaken to check whether a similar difference also exists during pseudopregnancy.

Adult female mice of a random-bred stock were housed individually and vaginal smears were taken daily throughout the study. Ovine prolactin (NIHPL-S10) dissolved in $0.9 \%$ saline (with a few drops of $0.1 \mathrm{~N}-\mathrm{NaOH}$ ) was injected intraperitoneally daily starting on the day of full vaginal cornification (oestrus) for 2 days or until the next oestrous smear. A treatment cycle of 9-14 days in length was considered as pseudopregnancy. The mean length of the treatment cycle in the various groups was compared by an analysis of variance and Duncan's test, while the incidence of pseudopregnancy was compared by the $\chi^{2}$ test for heterogeneity.

In untreated control animals, the length of the cycle was $4.03 \pm 0.02$ days and spontaneous occurrence of pseudopregnancy was never observed. Administration of prolactin for 2 days only, regardless of dose, or daily treatment with $12.5 \mu \mathrm{g}$ prolactin had no effect, while all other doses of prolactin caused a significant increase in the length of the cycle (Table 1). Pseudopregnancy was induced in 18/19 animals given a minimum of $50 \mu \mathrm{g}$ prolactin/day. Administration of 50 $\mu \mathrm{g}$ prolactin for 2 days followed by $25 \mu \mathrm{g}$ prolactin daily was significantly more effective than treatment with $25 \mu \mathrm{g}$ prolactin/day throughout the cycle $\left(\chi^{2}=\right.$ $4.95 ; P<0.05)$ and induced pseudopregnancy in all animals. Treatment with $50 \mu \mathrm{g}$ prolactin for 2 days followed by $12.5 \mu \mathrm{g} /$ day appeared more effective than administration of $12.5 \mu \mathrm{g}$ prolactin throughout, but, the difference in the incidence of pseudopregnancy in the two groups was not statistically significant $\left(\chi^{2}=2 \cdot 72\right)$.

The results indicate that administration of prolactin for 2 days is not sufficient to induce pseudopregnancy in the mouse, a situation similar to that described for the rat (Anderson, 1968). During pseudopregnancy, the requirement for exogenous prolactin in the first 2 days after ovulation is greater than thereafter. We have noted a similar difference in the prolactin requirement in hereditary dwarf mice in which pregnancy was maintained by daily injections of ovine 
Table 1. Influence of ovine prolactin on the length of the cycle and on the incidence of pseudopregnancy in mice

\begin{tabular}{|c|c|c|}
\hline $\begin{array}{l}\text { Daily dose } \\
\text { of prolactin }\end{array}$ & $\begin{array}{c}\text { Mean }( \pm \text { S.E. }) \text { length of } \\
\text { treatment cycle } \\
(\text { days })\end{array}$ & $\begin{array}{c}\text { Incidence of } \\
\text { pseudopregnancy }\end{array}$ \\
\hline $\begin{array}{l}0 \text { (saline controls) } \\
500 \mu \mathrm{g} \text { for } 2 \text { days only } \\
50 \mu \mathrm{g} \text { for } 2 \text { days only } \\
500 \mu \mathrm{g}^{*} \\
250 \mu \mathrm{g}^{*} \\
150 \mu \mathrm{g}^{*} \\
75 \mu \mathrm{g}^{*} \\
50 \mu \mathrm{g}^{*} \\
25 \mu \mathrm{g}^{*} \\
12 \cdot 5 \mu \mathrm{g} * \\
50 \mu \mathrm{g} \text { for } 2 \text { days, then } 25 \mu \mathrm{g}^{*} \\
50 \mu \mathrm{g} \text { for } 2 \text { days, then } 12.5 \mu \mathrm{g}^{*}\end{array}$ & $\begin{array}{c}5 \cdot 0 \pm 0 \cdot 4^{\mathrm{a}} \\
5 \cdot 0 \pm 0 \cdot 6^{\mathrm{a}} \\
5 \cdot 0 \pm 0 \cdot 0^{\mathrm{a}} \\
11 \cdot 5 \pm 0 \cdot 9^{\mathrm{d}, \mathrm{e}} \\
11 \cdot 2 \pm 1 \cdot 0^{\mathrm{c}, \mathrm{d}, \mathrm{e}} \\
9 \cdot 2 \pm 2 \cdot 1^{\mathbf{b}, \mathrm{c}, \mathrm{d}} \\
14 \cdot 0 \pm 0 \cdot 0^{\mathrm{c}} \\
10 \cdot 8 \pm 1 \cdot 0^{\mathrm{c}, \mathrm{d}, \mathrm{e}} \\
8 \cdot 2 \pm 1 \cdot 0^{\mathrm{b}, \mathrm{c}} \\
6 \cdot 5 \pm 0 \cdot 9^{\mathrm{a}, \mathrm{b}} \\
11 \cdot 7 \pm 0 \cdot 8^{\mathrm{d}, \mathrm{e}} \\
10 \cdot 0 \pm 1 \cdot 0^{\mathrm{c}, \mathrm{d}}\end{array}$ & $\begin{array}{l}0 / 4 \\
0 / 3 \\
0 / 4 \\
4 / 4 \\
4 / 4 \\
3 / 4 \\
3 / 3 \\
4 / 4 \\
2 / 5 \\
1 / 4 \\
6 / 6 \\
4 / 5\end{array}$ \\
\hline
\end{tabular}

Groups with the same superscript letter are not significantly different from each other.

\footnotetext{
* Until next oestrous smear.
}

prolactin, but the required doses were considerably greater, $125 \mu \mathrm{g}$ prolactin/ day during the first 2 days after mating, and $62 \mu \mathrm{g} /$ day for the following 6 days (Bartke, 1973). This difference is even more pronounced if body weight of the animals is taken into consideration. Dwarf mice weighed approximately $14 \mathrm{~g}$ and normal mice approximately $22 \mathrm{~g}$. Since dwarfs used in our previous study and the normal mice used in the present investigation were of the same strain, the difference in prolactin requirement is probably due to the absence of endogenous prolactin in genetically dwarf animals (Bartke, 1966, 1973).

Supported by NIH (5 KO4 HD70369 and 5 R01 HD06867); we thank NIAMDD for prolactin and Susan Dalterio for statistical analysis. One of us (B.T.G.) was a summer student from Worcester Polytechnic Institute.

\section{REFERENCES}

ANDERSON, R.R. (1968) Lactogenic hormone requirement for pseudo-pregnancy in normal and hyster* ectomized rats. Proc. Soc. exp. Biol. Med. 127, 723-725.

BartKe, A. (1966) Reproduction of female dwarf mice treated with prolactin. F. Reprod. Fert. 11, 203206.

BARTKe, A. (1973) Differential requirement for prolactin during pregnancy in the mouse. Biol. Reprod. 9, 379-383.

BRownING, H.C. \& White, W.D. (1963) Luteotropic action of fractional and multiple pituitary isografts in the mouse. Texas Rep. Biol. Med. 31, 176-184.

Choudary, J.B. \& Greenwald, G.S. (1969) Luteotropic complex of the mouse. Anat. Rec. 163, 373-388.

Dominic, C.J. (1966) Effects of single ectopic pituitary grafts on the oestrous cycle of the intact mouse. 7. Reprod. Fert. 12, 533-538.

Dresel, I. (1935) The effect of prolactin on the estrus cycle of non-parous mice. Science, N.Y. 82, 173. 